\title{
Efficient carbon-Ferrier rearrangement on glycals mediated by ceric ammonium nitrate: Application to the synthesis of 2-deoxy-2-amino-C-glycoside
}

\begin{tabular}{|c|c|c|}
\hline Full Research Paper & & Open Access \\
\hline \multirow{3}{*}{$\begin{array}{l}\text { Address: } \\
\text { Department of Chemistry, Indian Institute of Technology Kanpur } 208 \\
\text { 016, India }\end{array}$} & Beilstein J. Org. Chem. 2014, 10, 300-306. & \\
\hline & doi:10.3762/bjoc. 10.27 & \\
\hline & Received: 29 October 2013 & \\
\hline Email: & Accepted: 09 January 2014 & \\
\hline Yashwant D. Vankar ${ }^{*}$ - vankar@iitk.ac.in & Published: 30 January 2014 & \\
\hline${ }^{*}$ Corresponding author & Associate Editor: N. Sewald & \\
\hline Keywords: & (C) 2014 Ansari et al; licensee Beilstein-Institut. & \\
\hline $\begin{array}{l}\text { C-glycosides; carbon-Ferrier rearrangement; ceric ammonium nitrate; } \\
\text { 2-deoxy-2-aminoglycosides; Overman rearrangement }\end{array}$ & License and terms: see end of document. & \\
\hline
\end{tabular}

\begin{abstract}
A carbon-Ferrier rearrangement on glycals has been performed by using ceric ammonium nitrate to obtain products in moderate to good yields with high selectivity. The versatility of this method has been demonstrated by applying it to differently protected glycals and by employing several nucleophiles. The obtained $C$-allyl glycoside has been utilized for the synthesis of a orthogonally protected 2-amino-2-deoxy- $C$-glycoside.
\end{abstract}

\section{Introduction}

The growing significance of $C$-glycosides can be attributed to their potential use as inhibitors of carbohydrate-processing enzymes [1-3], their extraordinary stability compared to $O$-glycosides, and their widespread applicability as intermediates in the synthesis of biologically important molecules [4-8] $C$-glycosides are also subunits of several biologically active natural products [9-11]. Consequently, numerous reports are available in literature on the synthesis of $C$-glycosides [12-14] Among these, the Ferrier rearrangement [15] of glycals with protic acids $[5,16,17]$ or Lewis acids [18-22] and carbon nucleophiles such as allylsilanes [23], silylacetylenes [24], silyl enol ethers [25], olefins [26], and organozinc reagents [27] has emerged as a popular method. In particular, $C$-allyl glycosides, glycosyl cyanides, and glycosyl azides have received considerable attention, as the allyl, cyanide and azide moieties can be readily converted into a variety of other functional groups [6,28-30]. Furthermore, the resulting $C$-pseudoglycals are also important as the double bond can also be easily functionalized in a variety of ways.

Although there is an abundance of methods reporting on the carbon-Ferrier rearrangement of glycals [9], efforts are ongoing for improvements in terms of efficiency, selectivity, time and yields of reaction. In view of our continued interest in the development of novel methods for the synthesis of $O$ - and $C$-glycosides [31-36], we here report on the carbon-Ferrier rearrange- 
ment of glycals by using ceric ammonium nitrate. Ceric ammonium nitrate (CAN) is a versatile and efficient reagent, which has been well-explored for a variety of reactions in literature $[37,38]$. CAN was utilized successfully in carbohydrate chemistry for important transformations such as the azidonitration of glycals and the formation of 2-C-branched glycosides from glycals [39-41]. In this paper, we report on the addition of carbon nucleophiles onto differently protected glycals by using CAN. The corresponding Ferrier rearrangement products were obtained in moderate to fairly good yields and with a high selectivity.

\section{Results and Discussion}

We initially performed the carbon-Ferrier rearrangement on 3,4,6-tri- $O$-acetyl-D-glucal (1a) by using 3 equivalents of allyltrimethylsilane and 2 equivalents of CAN in anhydrous acetonitrile at room temperature. The reaction proceeded smoothly over 1 hour and exclusively furnished the $\alpha$ - $C$-allyl glycoside 2a in $88 \%$ yield (Table 1) [42]. We attempted the same reaction with a catalytic amount (10-30 mol \%) of CAN. However, under these conditions the reaction showed complicated TLC profiles and did not complete even after overnight stirring or heating under reflux for several hours. Changing the solvent to dichloromethane slowed down the reaction considerably due to the poor solubility of CAN, whereas in acetone the reaction gave lower yields. After several optimization experiments, the reaction was observed to be most efficient when 2 equivalents of silane and one equivalent of CAN, with respect to the glycal, was used in acetonitrile.

The reaction was then carried out with several glycals (Table 2). and yielded a single product in all cases studied. In the case of glycals 1a-d, only the $\alpha$-anomer was obtained as has been reported by Danishefsky et al. in the first report on the $C$-glycosidation of glycals with allyltrimethylsilane by using $\mathrm{TiCl}_{4}$ [23]. The spectral data of the obtained $C$-allyl glycosides

Table 1: Optimization of reaction conditions.

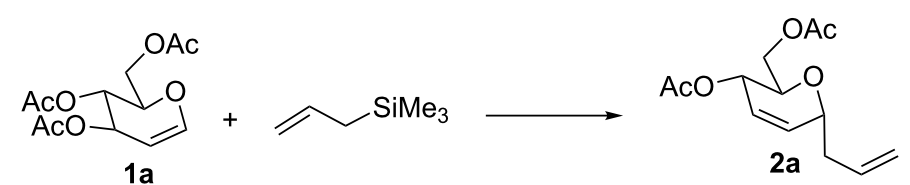

\begin{tabular}{|c|c|c|c|c|c|c|}
\hline Entry & Silane (equiv) & CAN (equiv) & Solvent & Temp $\left({ }^{\circ} \mathrm{C}\right)$ & Time (h) & Yield (\%) \\
\hline 1 & 3.0 & 2.0 & $\mathrm{CH}_{3} \mathrm{CN}$ & $\mathrm{rt}$ & $1 \mathrm{~h}$ & 88 \\
\hline 2 & 3.0 & 0.2 & $\mathrm{CH}_{3} \mathrm{CN}$ & reflux & $12 \mathrm{~h}$ & 38 \\
\hline 3 & 3.0 & 0.5 & $\mathrm{CH}_{3} \mathrm{CN}$ & reflux & $12 \mathrm{~h}$ & 45 \\
\hline 4 & 3.0 & 1.0 & $\mathrm{CH}_{3} \mathrm{CN}$ & $\mathrm{rt}$ & $1.5 \mathrm{~h}$ & 82 \\
\hline 5 & 2.0 & 1.0 & $\mathrm{CH}_{3} \mathrm{CN}$ & $\mathrm{rt}$ & $2 \mathrm{~h}$ & 88 \\
\hline 6 & 2.0 & 1.0 & $\mathrm{CH}_{3} \mathrm{COCH}_{3}$ & $\mathrm{rt}$ & $6 \mathrm{~h}$ & 53 \\
\hline 7 & 2.0 & 1.0 & $\mathrm{CH}_{2} \mathrm{Cl}_{2}$ & $\mathrm{rt}$ & $12 \mathrm{~h}$ & 20 \\
\hline
\end{tabular}

Table 2: Reaction of glycals with allyltrimethylsilane by using CAN

Entry


Table 2: Reaction of glycals with allyltrimethylsilane by using CAN. (continued)

3

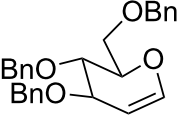

$1 \mathrm{c}$

4

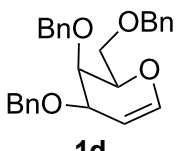

1d

5

6

7

8

9<smiles>CC(=O)OC1CCOCC1OC(C)=O</smiles>

1e

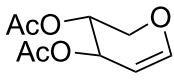

$1 f$

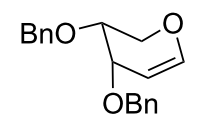

$1 \mathrm{~g}$

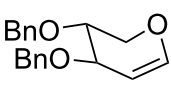

$1 \mathrm{~h}$

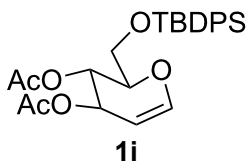

10.

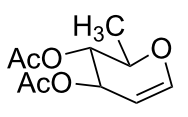

$1 \mathrm{j}$

11.

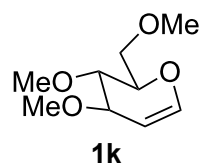

12.

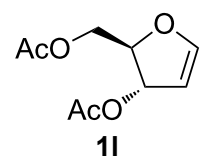

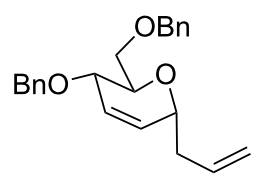

$4 \mathrm{~h}$

69

[42]

2c<smiles>C=CCC1C=CC(COCc2ccccc2)C(CBr)C1</smiles>

2d

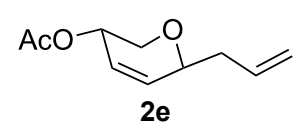

$2 \mathrm{~h}$

80

$[43,45]$

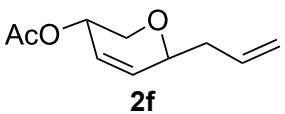

$3 \mathrm{~h}$

84<smiles>C=CCC1C=CC(OCc2ccccc2)CO1</smiles>

$4 \mathrm{~h} \quad 71$

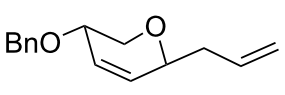

2g<smiles>C=CCC1C=CC(OC(C)=O)C(CO[Pb])C1</smiles>

$2 \mathbf{i}$<smiles>C=CCC1C=CC(OC(C)=O)C(C)O1</smiles>

$4 \mathrm{~h} \quad 66$

[43]

2j<smiles>C=CCC1C=CC(OC)C(COC)C1COC</smiles>

$2 \mathrm{~h}$

78

[43]

2k<smiles>C=CC[C@@H]1C=[C]C(COC(C)=O)O1</smiles>

supported the known data [42-44]. In general, D-glucals were found to react faster than D-galactals and provided the rearranged products in less time and better yields. Moreover, even the benzylated glycals $\mathbf{1 c}$ and $\mathbf{1 d}$ readily underwent the Ferrier rearrangement under these conditions. The pentose glycals 1e-h exclusively gave the anti-products, confirming previous investigations [45]. Glycals 1i, with a TBDPS protecting group, and $\mathbf{1} \mathbf{k}$, with a methyl protecting group, were also found to undergo the reaction in good yields affording $\mathbf{2 i}$ (see Supporting Information File 1) and 2k [42], respectively. These findings indicate that the protecting groups were not affected by this reagent system. D-rhamnal $\mathbf{1 j}$ and D-ribose 
derived glycal 11 [46] yielded hitherto unknown $C$-allyl glycosides $\mathbf{2} \mathbf{j}$ and $\mathbf{2 1}$, respectively (see Supporting Information File 1). However, the same reaction with benzylidene or isopropylidene glucals resulted in a complex mixture of products and the desired product was not isolated.

Furthermore, the scope of this reaction was extended by subjecting glycals to reactions with other nucleophiles. Thus, glycals $1 \mathrm{a}$ and $\mathbf{1 b}$ subjected to treatment with $\mathrm{Me}_{3} \mathrm{SiCN}$ afforded a 5:1 and 4:1 mixture of glycosyl cyanides 3 and $\mathbf{4}$ in $77 \%$ and $62 \%$ yields, respectively (Table 3 ). The reaction of glycals $1 \mathrm{a}$ and $\mathbf{1 b}$ with $\mathrm{Me}_{3} \mathrm{SiN}_{3}$ furnished a mixture of $\mathrm{C}-1$ and C-3 substituted glycosyl azides (5/5' and 6/6'). This observation is in conformity with the report of Hayashi and co-workers [47], which described the obtainment of Ferrier products along with C-3 substituted products. On the other hand, glucal 1a on reaction with triethylsilane afforded the product 7 in $43 \%$ yield, while galactal $\mathbf{1 b}$ gave a complex mixture of products, which could not be analyzed.

\section{Proposed mechanism}

The proposed mechanism of the formation of the $C$-allyl glycosides is shown in Scheme 1. The ring oxygen could donate an electron to the $\mathrm{Ce}^{3+}$ leading to the formation of a radical cation A. Subsequent migration of the double bond and loss of the acetyl radical could result in the formation of the delocalized carbocation $\mathbf{B}$. The acetate radical could accept an electron from $\mathrm{Ce}^{2+}$ thereby forming an acetate anion, which could in turn attack the silyl moiety of allyltrimethylsilane leading to the formation of trimethylsilyl acetate and an allyl anion. The allyl

Table 3: Reaction of glycals with other nucleophiles.

\begin{tabular}{|c|c|c|c|c|c|c|}
\hline Entry & Glycal & Nucleophile & Product(s) & Time & Yield & Ref. \\
\hline 1 & $1 \mathrm{a}$ & TMSCN & 3 & $6 \mathrm{~h}$ & 77 & {$[42]$} \\
\hline 2 & $1 \mathrm{~b}$ & TMSCN & 4 & $12 \mathrm{~h}$ & 62 & {$[42]$} \\
\hline 3 & $1 a$ & $\mathrm{TMSN}_{3}$ & & $3 \mathrm{~h}$ & 69 & {$[42,47]$} \\
\hline 4 & $1 b$ & $\mathrm{TMSN}_{3}$ & & $4 \mathrm{~h}$ & 59 & {$[42,47]$} \\
\hline 5 & $1 a$ & $\mathrm{Et}_{3} \mathrm{SiH}$ & 7 & $2 \mathrm{~h}$ & 43 & [43] \\
\hline
\end{tabular}
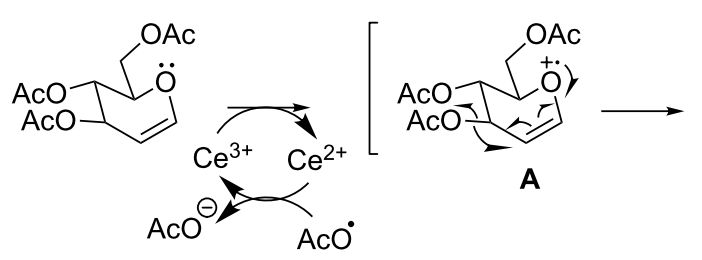
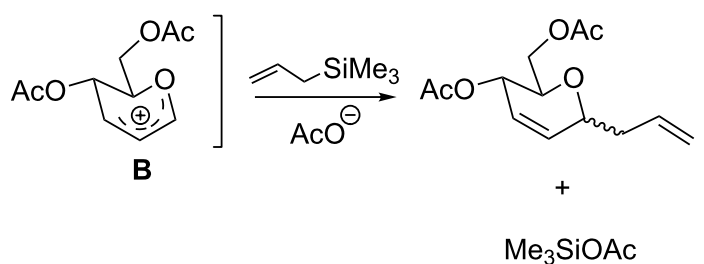
anion could then attack at the anomeric position so that the C-allyl pseudoglycoside is fomed. However, we were not able to isolate $\mathrm{Me}_{3} \mathrm{SiOAc}$. As the acetate ion and the acetyl radical are better leaving groups the formation of the acyl radical seems to be more facile than the formation of the alkoxy radicals (e.g., benzyloxy and methoxy). This explains faster reaction times in the case of acetylated glycals compared to benzyl or methyl glycals. It is well-known in the literature that the participation of a neighboring group is possible in the case of glucals thereby leading to a higher reactivity than the corresponding galactals $[48,49]$.

Having obtained the $\alpha$ - $C$-glycosides in an efficient manner, we explored their synthetic utility to synthesize a 2-deoxy-2-amino$\alpha$ - $C$-glycoside. 2-Deoxy-2-amino- $\alpha$ - $C$-glycosides have received considerable attention in recent years due to their use in the synthesis of glycopeptides [50,51], glycolipids [51] and glycosyl amino acids [52] to name but a few. Amongst the various reported methods to prepare these compounds [53-55], the most common method is via C-glycosylation of 2-aminosugars [5658 ], which is challenging owing to the incompatibility of protic or Lewis acids with amino and amido functionality. In particular, very few reports on the synthesis of orthogonally protected C-glycosides appeared in literature [59]. Therefore, there is a need for the development of efficient methods to allow easy access to this important class of compounds.

For this purpose, Ferrier rearranged product 2a was subjected to deacetylation by using $\mathrm{K}_{2} \mathrm{CO}_{3} / \mathrm{MeOH}$ (Scheme 2) followed by the selective protection of the primary hydroxy group as a benzyl ether by using $\mathrm{Bu}_{2} \mathrm{SnO}$ and benzyl bromide in the presence of triethylamine and tetrabutylammonium iodide to afford alcohol 8 in $69 \%$ yield over 2 steps. The terminal olefin in compound 8 was then subjected to a Wacker oxidation [60] by using a catalytic amount of $\mathrm{PdCl}_{2}$ and an excess of $\mathrm{CuCl}$ under $\mathrm{O}_{2}$ atmosphere to obtain the methyl ketone 9 in a good yield. The formation of the product was confirmed by the disappearance of the external olefinic protons and the appearance of a sharp singlet at $\delta 2.11$, corresponding to methyl protons in the ${ }^{1} \mathrm{H}$ NMR spectrum, as well as a peak at $\delta 207 \mathrm{ppm}$ in the ${ }^{13} \mathrm{C}$ NMR spectrum corresponding to the carbonyl group (see Supporting Information File 1). The allylic alcohol 9 was converted to the corresponding trichloroacetimidate, which in crude form was heated under reflux in xylene, to afford the single isomer $\mathbf{1 0}$ in $72 \%$ yield by an Overman rearrangement [61-63].

The trichloroacetamide group was hydrolyzed by heating under reflux in $6 \mathrm{~N} \mathrm{HCl}$, and the obtained free amine was protected as a benzyloxycarbamate group by using benzyl chloroformate and $\mathrm{Na}_{2} \mathrm{CO}_{3}$. The protected amide 11 was obtained in $74 \%$ yield over 2 steps. The regioselectivity of the Overman rearrangement step was determined from the ${ }^{1} \mathrm{H}$ NMR and COSY experiments of compound 11. These experiments showed that the anomeric proton $(\mathrm{H}-1)$ at $\delta 4.40$ correlated with the $\mathrm{H}-2$ proton at $\delta 4.00$, which in turn was adjacent to the amide proton at $\delta 4.85$, thereby indicating that the amide moiety is present at the C-2 position (see Supporting Information File 1). The internal olefin was subjected to a dihydroxylation under the Upjohn conditions [64], followed by an acetonide protection of the<smiles></smiles>

$2 a$
1. $\mathrm{K}_{2} \mathrm{CO}_{3}, \mathrm{MeOH}, \mathrm{rt}, 2 \mathrm{~h}$

2. $n-\mathrm{Bu}_{2} \mathrm{SnO}, \mathrm{PhCH}_{3}, 120^{\circ} \mathrm{C}, 6 \mathrm{~h}$

3. $\mathrm{Et}_{3} \mathrm{~N}, n-\mathrm{Bu}_{4} \mathrm{~N}^{+} \mathrm{I}^{-}, \mathrm{BnBr}, 120^{\circ} \mathrm{C}$, 2 h, $69 \%$ over 2 steps \begin{tabular}{l} 
1. $\mathrm{Cl}_{3} \mathrm{CCN}, \mathrm{DBU}$, \\
$\mathrm{CH}_{2} \mathrm{Cl}_{2}, 0^{\circ} \mathrm{C}$ \\
\hline
\end{tabular}

2. xylene, reflux overnight, $72 \%$<smiles>CC(=O)C[C@H]1O[C@@H](COCc2ccccc2)C=C[C@H]1NC(=O)C(Cl)(Cl)Cl</smiles>

10<smiles>C=CC[C@@H]1C=CC(O)C(COCc2ccccc2)O1</smiles>

8

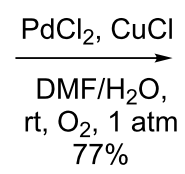

$\mathrm{O}_{2}, 1$
$77 \%$<smiles>CC(=O)OC(=O)C[C@H]1O[C@H](COCc2ccccc2)C=C[C@H]1N</smiles>
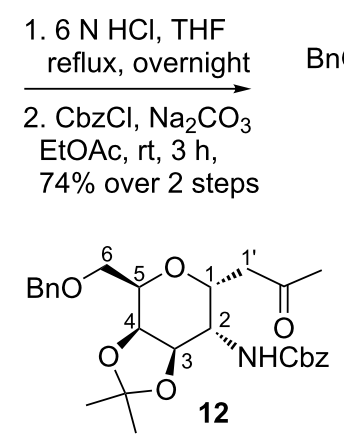
resulting diol by using 2,2-dimethoxypropane and a catalytic amount of para-toluenesulfonic acid (PTSA) to furnish the desired orthogonally protected 2-deoxy-2-amino- $C$-glycoside 12 as a single isomer in $82 \%$ yield (over 2 steps).

The stereochemistry of the newly generated stereocenters in compound 12 was determined with the help of ${ }^{1} \mathrm{H}$ NMR, COSY, nOe and decoupling experiments (Figure 1). Thus, the irradiation of the signal at $\delta 3.93$ corresponding to $\mathrm{H}-3$ led to an enhancement of the H-5 signal at $\delta 4.25$ by $2.5 \%$, while the peak at $\delta 4.63$, corresponding to $\mathrm{H}-1$, was not enhanced. This implies that the H-3 proton is cis to $\mathrm{H}-5$ and trans to $\mathrm{H}-1$ and thus axially oriented. Meanwhile, the irradiation of the H-1 signal at $\delta 4.63$ did not give any enhancement of the $\mathrm{H}-3$ and $\mathrm{H}-5$ peaks at $\delta 3.93$ and $\delta 4.25$, respectively. Moreover, the homonuclear decoupling of the $\mathrm{H}-3$ signal at $\delta 3.93$ gave the coupling constant of $\mathrm{H}-4$ and $\mathrm{H}-5$ as $J=7.3 \mathrm{~Hz}$, which indicates an axial-equatorial relationship. The decoupling of the $\mathrm{H}-1$ ' signals at $\delta 2.55$ provided the coupling constant of $\mathrm{H}-1$ and $\mathrm{H}-2$ as $J=6.4 \mathrm{~Hz}$, indicating an axial-equatorial relationship (see Supporting Information File 1). This suggests that the rearrangement took place from the axial side, as expected, since the hydroxy group at C-4 is axially oriented in compound $\mathbf{9}$. Moreover, the dihydroxylation took place from the side opposite to the amino group at $\mathrm{C}-2$, which can be attributed to the steric hindrance from the bulky amide group.
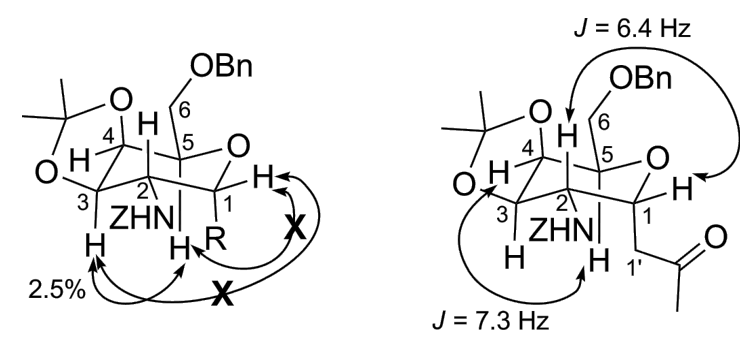

Figure 1: nOe and decoupling experiments of compound 12.

A D-galacto-configured C-glycoside $\mathbf{1 2}$ was obtained from D-glucal 1a, which may serve as a versatile synthetic intermediate, since the carbonyl moiety and the double bond functionality in this compound can be synthetically manipulated in a variety of ways.

\section{Conclusion}

We have developed an efficient method for the Ferrier rearrangement of glycals by using ceric ammonium nitrate and several carbon nucleophiles. We have successfully employed the obtained $C$-allyl glycoside 2a for the stereoselective synthesis of a orthogonally protected 2-deoxy-2-amino- $C$-glycoside 12 via an Overman rearrangement as a key step.

\section{Supporting Information}

\section{Supporting Information File 1}

Analytical data and copies of the ${ }^{1} \mathrm{H}$ NMR and ${ }^{13} \mathrm{C}$ NMR

spectra of all new compounds.

[http://www.beilstein-journals.org/bjoc/content/

supplementary/1860-5397-10-27-S1.pdf]

\section{Acknowledgements}

We thank the Department of Science and Technology, New Delhi, for a J. C. Bose National Fellowship (JCB/SR/S2/JCB26/2010) and the Council of Scientific and Industrial Research, New Delhi, for financial support [Grant No. 01(2298)/09/EMRII] to Y.D.V. A.A.A. and Y.S.R. gratefully acknowledge a Senior Research Fellowship from the Council of Scientific Industrial Research, New Delhi.

\section{References}

1. Zou, W. Curr. Top. Med. Chem. 2005, 5, 1363-1391. doi:10.2174/156802605774642999

2. Sutherlin, D. P.; Stark, T. M.; Hughes, R.; Armstrong, R. W. J. Org. Chem. 1996, 61, 8350-8354. doi:10.1021/jo960119j

3. Weatherman, R. V.; Mortell, K. H.; Chervenak, M.; Kiessling, L. L.; Toone, E. J. Biochemistry 1996, 35, 3619-3624. doi:10.1021/bi951916z

4. Danishefsky, S. J.; DeNinno, S.; Lartey, P. J. Am. Chem. Soc. 1987, 109, 2082-2089. doi:10.1021/ja00241a028

5. Paterson, I.; Keown, L. E. Tetrahedron Lett. 1997, 38, 5727-5730. doi:10.1016/S0040-4039(97)01257-4

6. Kira, K.; Isobe, M. Tetrahedron Lett. 2000, 41, 5951-5955. doi:10.1016/S0040-4039(00)00988-6

7. Gallagher, B. M., Jr.; Zhao, H.; Pesant, M.; Fang, F. G. Tetrahedron Lett. 2005, 46, 923-926. doi:10.1016/j.tetlet.2004.12.056

8. Sasaki, M.; Tsubone, K.; Shoji, M.; Oikawa, M.; Shimamoto, K.; Sakai, R. Bioorg. Med. Chem. Lett. 2006, 16, 5784-5787. doi:10.1016/j.bmcl.2006.08.082

9. Fraser-Reid, B. Acc. Chem. Res. 1985, 18, 347-354. doi:10.1021/ar00119a004

10. Kirshning, A.; Chen, G.-w.; Dräger, G.; Schuberth, I.; Tietze, L. F. Bioorg. Med. Chem. 2000, 8, 2347-2354. doi:10.1016/S0968-0896(00)00166-8

11. Faul, M. M.; Huff, B. E. Chem. Rev. 2000, 100, 2407-2474. doi:10.1021/cr940210s

12. Dondoni, A.; Marra, A. Chem. Rev. 2000, 100, 4395-4422. doi:10.1021/cr9903003

13. Du, Y.; Linhardt, R. J.; Vlahov, I. R. Tetrahedron 1998, 54, 9913-9959. doi:10.1016/S0040-4020(98)00405-0

14. Ansari, A. A.; Lahiri, R.; Vankar, Y. D. ARKIVOC 2013, No. ii, 316-362. doi:10.3998/ark.5550190.0014.223

15. Ferrier, R. J. J. Chem. Soc. 1964, 5443-5449. doi:10.1039/JR9640005443

16. Yadav, J. S.; Satyanarayana, M.; Balanarsaiah, E.; Raghavendra, S. Tetrahedron Lett. 2006, 47, 6095-6098. doi:10.1016/j.tetlet.2006.06.084 
17. Tiwari, P.; Agnihotri, G.; Misra, A. K. Carbohydr. Res. 2005, 340, 749-752. doi:10.1016/j.carres.2004.12.022

18. De Las Heras, F. G.; Felix, A. S.; Fernández-Resa, P. Tetrahedron 1983, 39, 1617-1620. doi:10.1016/S0040-4020(01)88571-9

19. Ghosh, R.; De, D.; Shown, B.; Maiti, S. B. Carbohydr. Res. 1999, 321, 1-3. doi:10.1016/S0008-6215(99)00219-0

20. Yadav, J. S.; Reddy, B. V. S.; Chand, P. K. Tetrahedron Lett. 2001, 42, 4057-4059. doi:10.1016/S0040-4039(01)00629-3

21. Balamurugan, R.; Koppolu, S. R. Tetrahedron 2009, 65, 8139-8142. doi:10.1016/j.tet.2009.07.087

22. Takhi, M.; Rahman, A. A.-H. A.; Schmidt, R. R. Tetrahedron Lett. 2001, 42, 4053-4056. doi:10.1016/S0040-4039(01)00628-1

23. Danishefsky, S. J.; Kerwin, J. F., Jr. J. Org. Chem. 1982, 47, 3803-3805. doi:10.1021/jo00140a053

24. Ichikawa, Y.; Isobe, M.; Konobe, M.; Goto, T. Carbohydr. Res. 1987, 171, 193-199. doi:10.1016/S0008-6215(00)90886-3

25. Dawe, R. D.; Fraser-Reid, B. J. Chem. Soc., Chem. Commun. 1981, 1180-1181. doi:10.1039/C39810001180

26. Gemmell, N.; Meo, P.; Osborn, H. M. I. Org. Lett. 2003, 5, 1649-1652. doi:10.1021/ol030023t

27. Steinhuebel, D. P.; Fleming, J. J.; Du Bois, J. Org. Lett. 2002, 4, 293-295. doi:10.1021/ol010273e

28. Hanessian, S.; Pernet, A. G. Adv. Carbohydr. Chem. Biochem. 1976, 33, 111-188. doi:10.1016/S0065-2318(08)60281-4

29. Daves, G. D., Jr.; Cheng, C. C. Prog. Med. Chem. 1976, 13, 303-349. doi:10.1016/S0079-6468(08)70141-3

30. Poonian, M. S.; Nowoswiat, E. F. J. Org. Chem. 1980, 45, 203-208. doi:10.1021/jo01290a002

31. Gupta, A.; Vankar, Y. D. Tetrahedron 2000, 56, 8525-8531. doi:10.1016/S0040-4020(00)00775-4

32. Pachamuthu, K.; Vankar, Y. D. J. Org. Chem. 2001, 66, 7511-7513. doi:10.1021/j00103322

33. Agarwal, A.; Rani, S.; Vankar, Y. D. J. Org. Chem. 2004, 69, 6137-6140. doi:10.1021/jo049415j

34. Babu, J. L.; Khare, A.; Vankar, Y. D. Molecules 2005, 10, 884-892. doi:10.3390/10080884

35. Gupta, P.; Kumari, N.; Agarwal, A.; Vankar, Y. D. Org. Biomol. Chem. 2008, 6, 3948-3956. doi:10.1039/b810654a

36. Jayakanthan, K.; Vankar, Y. D. Carbohydr. Res. 2005, 340, 2688-2692. doi:10.1016/j.carres.2005.07.024

37. Sridharan, V.; Menéndez, J. C. Chem. Rev. 2010, 110, 3805-3849. doi:10.1021/cr100004p

38. Nair, V.; Balagopal, L.; Rajan, R.; Mathew, J. Acc. Chem. Res. 2004, 37, 21-30. doi:10.1021/ar030002z

39. Agarwal, A.; Vankar, Y. D. Proc. Indian Natl. Sci. Acad., Part A 2005, 71, 309-326.

40. Linker, T.; Sommermann, T.; Kahlenberg, F. J. Am. Chem. Soc. 1997, 119, 9377-9384. doi:10.1021/ja971084n

41. Yin, J.; Sommermann, T.; Linker, T. Chem.-Eur. J. 2007, 13, 10152-10167. doi:10.1002/chem.200701151

42. Yadav, J. S.; Reddy, B. V. S. Synthesis 2002, 511-514. doi:10.1055/s-2002-20968

43. Ghosh, R.; Chakraborty, A.; Maiti, S. B. ARKIVOC 2004, xiv, 1-9. doi:10.3998/ark.5550190.0005.e01

44. Lin, H.-C.; Du, W.-P.; Chang, C.-C.; Lin, C.-H. Tetrahedron Lett. 2005, 46, 5071-5076. doi:10.1016/j.tetlet.2005.05.061

45. Hosokawa, S.; Kirschbaum, B.; Isobe, M. Tetrahedron Lett. 1998, 39, 1917-1920. doi:10.1016/S0040-4039(98)00047-1

46. Brawn, R. A.; Panek, J. S. Org. Lett. 2010, 12, 4624-4627. doi:10.1021/ol1019629
47. Kawabata, H.; Kubo, S.; Hayashi, M. Carbohydr. Res. 2001, 333, 153-158. doi:10.1016/S0008-6215(01)00128-8

48. Ferrier, R. J.; Zubkov, O. A. Org. React. 2004, 569-736.

49. Gómez, A. M.; Lobo, F.; Uriel, C.; López, J. C. Eur. J. Org. Chem. 2013, 7221-7262. doi:10.1002/ejoc.201300798 See for a recent review.

50. Wang, L.-X.; Fan, J.-Q.; Lee, Y. C. Tetrahedron Lett. 1996, 37, 1975-1978. doi:10.1016/0040-4039(96)00261-4

51. McGarvey, G. J.; Benedum, T. E.; Schmidtmann, F. W. Org. Lett. 2002, 4, 3591-3594. doi:10.1021/ol0264861

52. Westermann, B.; Walter, A.; Diedrichs, N. Angew. Chem., Int. Ed. 1999, 38, 3384-3386. doi:10.1002/(SICI)1521-3773(19991115)38:22<3384::AID-ANIE3384>3 .0.CO;2-7

53. Cipolla, L.; La Ferla, B.; Lay, L.; Peri, F.; Nicotra, F. Tetrahedron: Asymmetry 2000, 11, 295-303. doi:10.1016/S0957-4166(99)00480-2

54. Cipolla, L.; Lay, L.; Peri, F.; Nicotra, F. J. Org. Chem. 1997, 62, 6678-6681. doi:10.1021/jo970127f

55. Petrušová, M.; BeMiller, J. N.; Petruš, L. Tetrahedron Lett. 1996, 37 , 2341-2344. doi:10.1016/0040-4039(96)00280-8

56. SanMartin, R.; Tavassoli, B.; Walsh, K. E.; Walter, D. S.; Gallagher, T. Org. Lett. 2000, 2, 4051-4054. doi:10.1021/ol006682c

57. Urban, D.; Skrydstrup, T.; Beau, J.-M. Chem. Commun. 1998, 955-956. doi:10.1039/a801196f

58. Urban, D.; Skrydstrup, T.; Beau, J.-M. J. Org. Chem. 1998, 63, 2507-2516. doi:10.1021/jo971727h

59. Bouvet, V. R.; Ben, R. N. J. Org. Chem. 2006, 71, 3619-3622. doi:10.1021/jo051938j And references therein.

60. Tsuji, J. Palladium Reagents and Catalysts; Wiley: Chichester, 2004; pp 29-35.

61. Overman, L. E. J. Am. Chem. Soc. 1976, 98, 2901-2910. doi:10.1021/ja00426a038

62. Mercer, G. J.; Yang, J.; McKay, M. J.; Nguyen, H. M. J. Am. Chem. Soc. 2008, 130, 11210-11218. doi:10.1021/ja803378k

63. Gupta, P.; Vankar, Y. D. Eur. J. Org. Chem. 2009, 1925-1933. doi:10.1002/ejoc.200801301

64. VanRheenen, V.; Kelly, R. C.; Cha, D. Y. Tetrahedron Lett. 1976, 17, 1973-1976. doi:10.1016/S0040-4039(00)78093-2

\section{License and Terms}

This is an Open Access article under the terms of the Creative Commons Attribution License (http://creativecommons.org/licenses/by/2.0), which permits unrestricted use, distribution, and reproduction in any medium, provided the original work is properly cited.

The license is subject to the Beilstein Journal of Organic Chemistry terms and conditions: (http://www.beilstein-journals.org/bjoc)

The definitive version of this article is the electronic one which can be found at:

doi:10.3762/bjoc. 10.27 